\title{
Unusual aetiology of a type 2 myocardial infarction: a case-based review
}

\author{
David Toma ${ }^{1}$, Tania-Emima Toma², Cristina Bologa ${ }^{3,4}$, and Cătălina Lionte ${ }^{3,4}$ \\ ${ }^{1}$ Sf. Spiridon Emergency County Hospital, Emergency Department, Iași, Romania \\ ${ }^{2}$ Sf. Maria Emergency Children's Hospital, General Paediatrics, Iași, Romania \\ 3 "Grigore T. Popa" University of Medicine and Pharmacy, School of Medicine, Internal Medicine and Clinical \\ Toxicology Department, Iași, Romania \\ ${ }^{4}$ Sf. Spiridon Emergency County Hospital, $2^{\text {nd }}$ Internal Medicine Clinic, Iași, Romania
}

[Received in October 2020; Similarity Check in October 2020; Accepted in March 2021]

Organophosphate pesticide (OP) poisoning is quite common and can cause cardiovascular complications and even direct myocardial injury. However, no guideline has included an acute poisoning as a potential cause for a type 2 myocardial infarction (MI) so far. Here we present a case of a 61-year-old woman brought by ambulance to emergency department one hour after accidental ingestion of an unknown quantity of a solution she used against flea infestation. The patient presented with dizziness, myosis, excessive sweating, hypersalivation, sphincteric incontinence, muscle fasciculation, tremor of the extremities, pale skin, alcoholic and pesticide breath odour. Even though we had no guidelines to fall back on, we successfully treated the patient with low-molecular-weight heparin, antiplatelets, statin, diltiazem, antidote therapy, and supportive care. Physicians should be aware that OP poisoning can induce type $2 \mathrm{MI}$ as a complication within a few hours since exposure, and emergency management should always include close cardiac monitoring.

KEY WORDS: cardiovascular events; organophosphate poisoning; toxicology

Type 2 myocardial infarction (MI) occurs as a consequence of imbalance between myocardial oxygen demand and supply and involves different mechanisms such as endothelial dysfunction of the coronary arteries, vasculitis, dysrhythmias, vasospasm, coronary embolism, severe bradyarrhythmia, respiratory failure with severe hypoxaemia, severe anaemia, and hypotension/shock (1). Although there is no specific mention of type $2 \mathrm{MI}$ in the wake of acute poisoning, MI has been reported after acute carbon monoxide (2) and organophosphate (OP) pesticide poisoning (3-6), but these cases are exceptionally rare.

It is known, however, that severe OP poisoning can cause direct myocardial injury (7) and several cardiovascular complications, including electrocardiogram (ECG) abnormalities, MI, impaired systolic and diastolic performance, functional remodelling, and histopathological findings (8). To the best of our knowledge, here we present the first case of type $2 \mathrm{MI}$ as a result of accidental acute OP poisoning in a 61-year-old woman without cardiovascular risk factors who was chronically occupationally exposed to OP pesticides.

Corresponding author: David Toma, Sf. Spiridon Emergency County Hospital, Emergency Department, Strada Ion Creanga 98, 700321 Iași, Romania, E-mail: tomadavidro@gmail.com

\section{CASE PRESENTATION}

A 61-year-old woman was brought to the emergency department (ED) by ambulance one hour after accidental ingestion of an unknown quantity of OP solution from a bottle she confused for a drink. She came from a rural area where she had worked in agriculture and had been occupationally exposed to OP, carbamate, and organochlorine pesticides through inhalation and skin contact for 10 years. She had a history of surgery for post-traumatic subdural haematoma three years before the accident, without other known cardiovascular risk factors. She presented with clinical signs and symptoms of dizziness, myosis, excessive sweating, hypersalivation, sphincteric incontinence, muscle fasciculation, tremor of the extremities, pale skin, and alcoholic and pesticide breath odour. Her Glasgow Coma Scale was 9, and she was uncooperative, which made taking clinical history very difficult. Her initial blood pressure was 200/100 $\mathrm{mmHg}$, and the first ECG in the ED showed narrow QRS-complex tachycardia with a heart rate of $122 / \mathrm{min}$. Arterial blood gas analysis revealed lactic acidosis $(\mathrm{pH}$ 7.26 ), lactate $6.3 \mathrm{mmol} / \mathrm{L}$, bicarbonate $18.8 \mathrm{mmol} / \mathrm{L}$, potassium $2.5 \mathrm{mmol} / \mathrm{L}$, calcium $1.05 \mathrm{mmol} / \mathrm{L}$. Laboratory findings detected leukocytosis $\left(16.93 \times 10^{3} / \mu \mathrm{L}\right)$, neutrophilia $\left(13.9 \times 10^{3} / \mu \mathrm{L}\right)$, hyperglycaemia $(12.71 \mathrm{mmol} / \mathrm{L})$, and an ethanol level of $215 \mathrm{mg} / \mathrm{dL}$. Relative reference ranges of our laboratory are: white blood cells $4-10 \times 10^{3} / \mu \mathrm{L}$, 
neutrophils $2-8 \times 10^{3} / \mu \mathrm{L}$, glucose $4.55-5.55 \mathrm{mmol} / \mathrm{L}$, and ethanol $<10 \mathrm{mg} / \mathrm{dL}$. Cardiac markers were also elevated upon ED admission: creatine kinase (CK) was $412 \mathrm{U} / \mathrm{L}$ (reference range 20-170 U/L), CK myocardial band (CKMB) $73 \mathrm{U} / \mathrm{L}$ (ref. range 2-25 U/L), lactate dehydrogenase (LDH) 292 U/L (ref. range 135-214 U/L), N-terminal probrain natriuretic peptide (NT-proBNP) $524 \mathrm{pg} / \mathrm{mL}$, cardiac troponin I (cTnI) $1.75 \mathrm{ng} / \mathrm{mL}$ (ref. range $0-0.02 \mathrm{ng} / \mathrm{mL}$ ), and GOT $32 \mathrm{U} / \mathrm{L}$ (ref. range 5-32 U/L). The plasma cholinesterase level was 279 U/L (range 5320-12920 U/L). Other biological parameters were within normal ranges.

These findings pointed to acute OP pesticide poisoning (based on muscarinic and nicotinic signs and symptoms), and treatment was immediately started in the ED with oxygen therapy face mask ( $4 \mathrm{~L} / \mathrm{min}$ ), intravenous (iv) antidote (combining $2 \mathrm{mg}$ atropine and the initial bolus of $250 \mathrm{mg}$ obidoxime), and gastric lavage. The patient was then transferred to a medical ward, where she regained full consciousness and became cooperative. Physical examination one hour after ED admission established 150/100 $\mathrm{mmHg}$ blood pressure, 122/min heart rate, and mydriatic pupils. She had a body mass index of $24.4 \mathrm{~kg} /$ $\mathrm{m}^{2}$, she denied smoking, and declared occasional alcohol drinking. ECG showed ST segment depression in leads V3-V4, T flat in D1, aVL, V5-V6, but no signs of hypokalaemia (Figure 1A). Antidote therapy continued with $1 \mathrm{mg}$ atropine every hour (with reassessment of heart rate and pupil diameter every $15 \mathrm{~min}$ ) and slow continuous iv obidoxime administration ( $1 \mathrm{~g} / 24 \mathrm{~h})$, combined with diazepam $(5 \mathrm{mg})$, which led to resolution of the muscarinic signs and muscle fasciculations within three hours of first antidote administration. ECG in the medical ward showed $48 \%$ ejection fraction of the left ventricle (LVEF), $24 \%$ fractional shortening (FS), calcification of the aortic knob, no valve lesion, and no segmental wall motion abnormalities or thrombi. Clinical observation continued hourly and showed mydriatic pupils. Paraclinical parameters were also monitored, and hydro-electrolyte correction was continued. Careful atropine administration also continued to control muscarinic signs and symptoms because of the initial sinus tachycardia.

Six hours after the initial assessment at the ED, cardiac enzymes and biomarkers were as follows: cTnI $2.89 \mathrm{ng} / \mathrm{mL}$, NT-proBNP 1314 pg/mL, CK 1389 U/L, CK-MB 104 U/L, TGO 89U/L, and LDH $354 \mathrm{U} / \mathrm{L}$. At $28 \mathrm{~h}$, their values peaked to cTnI $6.84 \mathrm{ng} / \mathrm{mL}$, NT-proBNP $14,774 \mathrm{pg} / \mathrm{mL}, \mathrm{CK}$ 2614 U/L, CK-MB 125 U/L, TGO 148 U/L, and LDH 484 U/L. ECG monitoring showed important ST segment elevation $>1 \mathrm{~mm}$ in DII, DIII, aVF, with ST depression in aVL, flat $T$ waves in V5, and negative T waves in V6 (Figure 1B). All this confirmed the diagnosis of the ST-segment elevation myocardial infarction (STEMI). Therapy with low-molecular-weight heparin (enoxaparin), antiplatelets (aspirin, clopidogrel), and a statin was initiated immediately, while antidote therapy continued. The patient was transferred to the Cardiology Department, where ECG showed an inferior STEMI and supraventricular tachycardia (Figure 1C). LVEF was at $46 \%$, one third of the basal inferolateral and inferior walls were hypokinetic, one third of the basal anterior interventricular septum dyskinetic, and the aortic valve was calcified. Emergency coronarography showed normal epicardial coronary arteries with no obvious

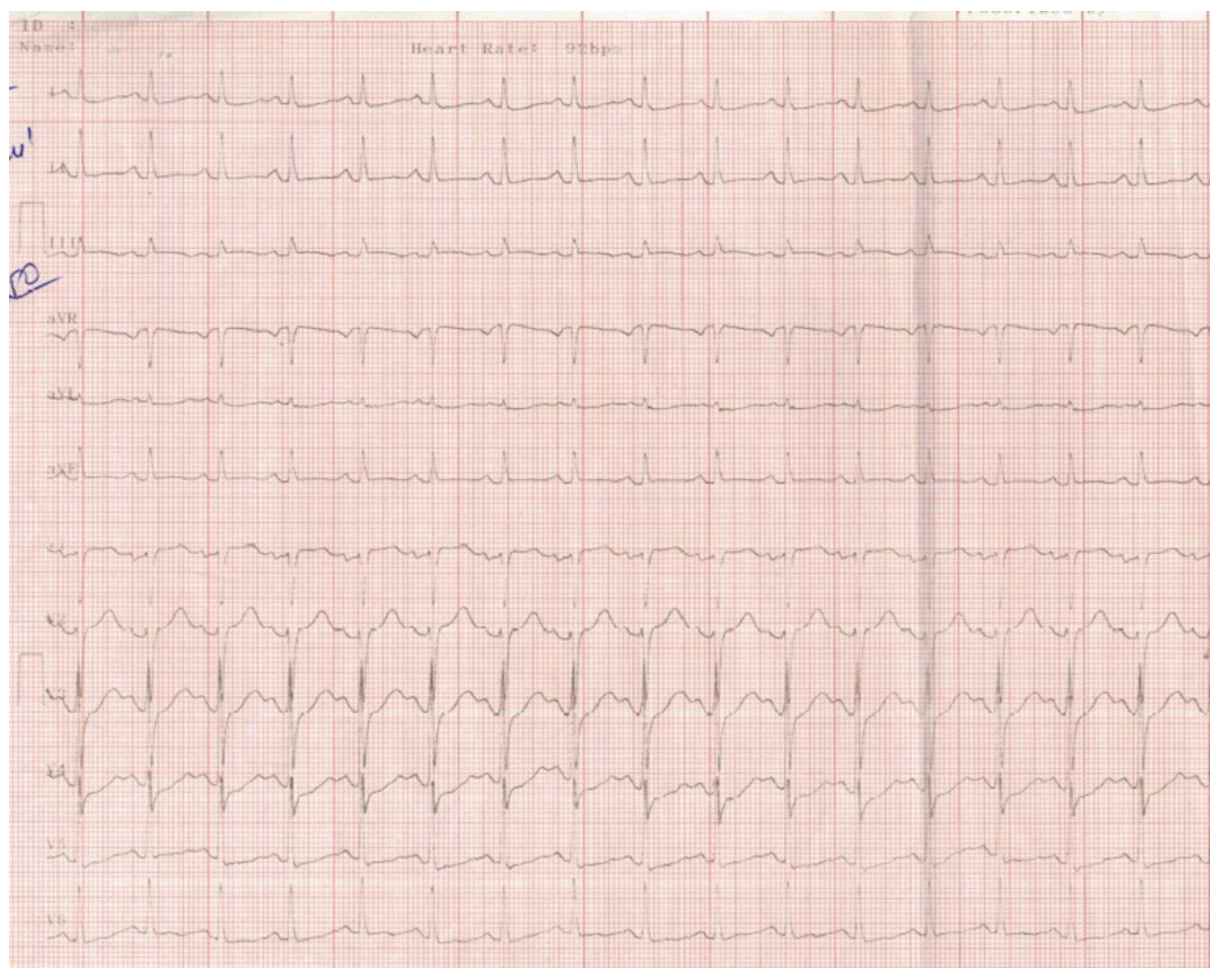

Figure 1A Electrocardiogram monitoring showing acute STEMI in inferior territory. ECG upon ED admission shows sinus rhythm, ST segment depression in V3-V4, and flat T waves in D1, aVL, V5-V6 


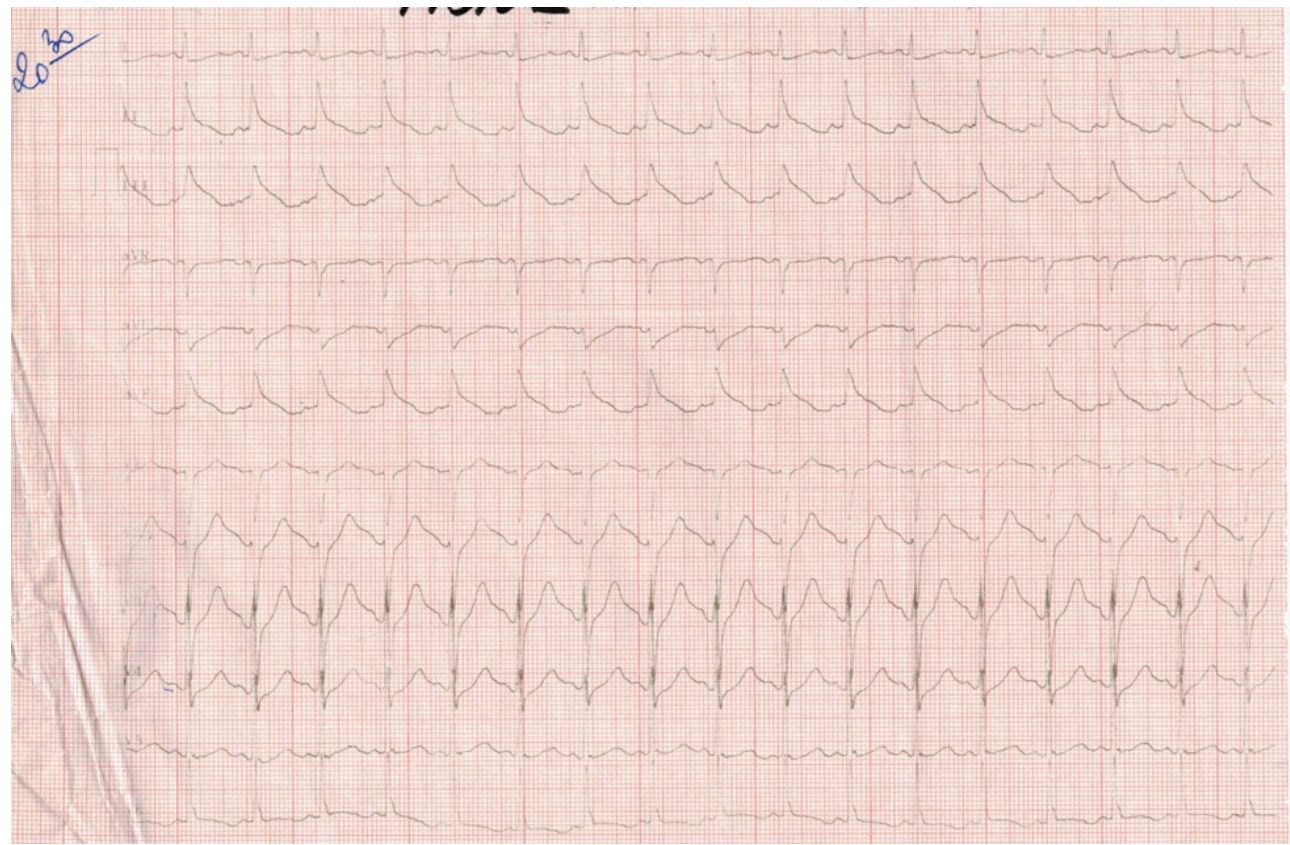

Figure 1B Electrocardiogram monitoring showing acute STEMI in inferior territory. ECG 26 hours after admission showed important ST segment elevation in leads DII, DIII, aVF, with S-T segment depression in aVL, flat T waves in DI, and V6, and sinus tachycardia

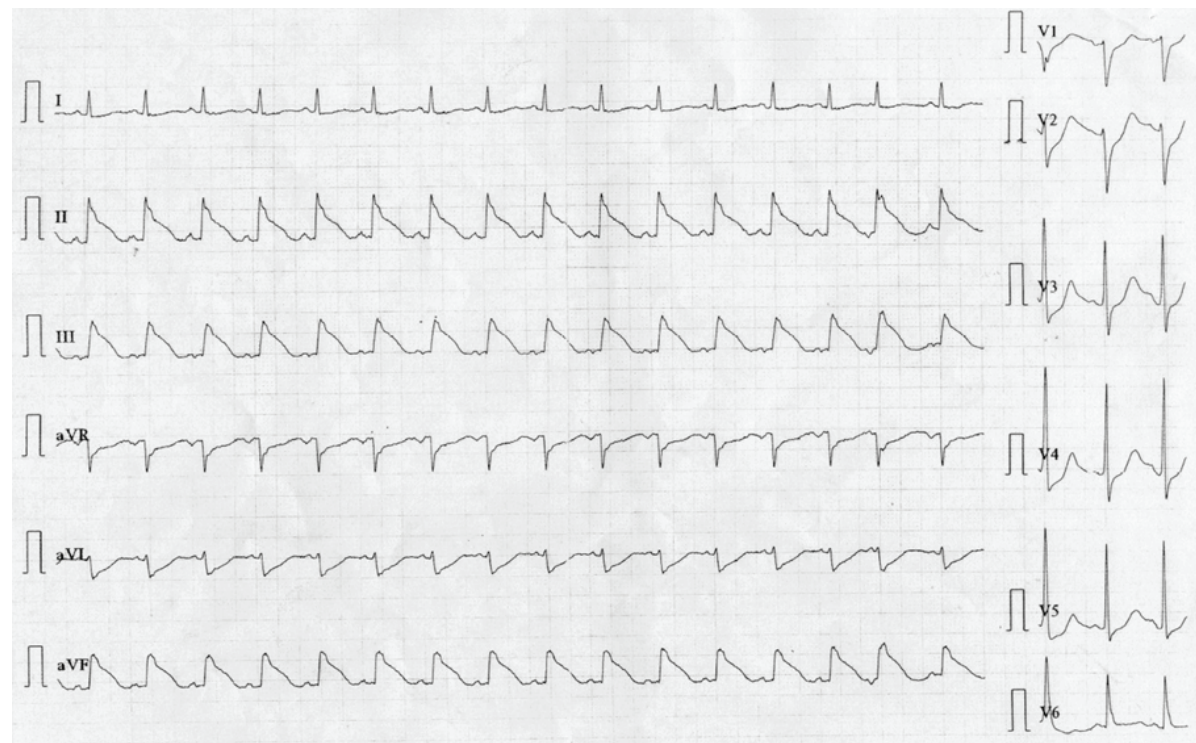

Figure 1C Electrocardiogram monitoring showing acute STEMI in inferior territory. ECG at the Cardiology Department revealed acute ST-elevation in inferior territory and sinus tachycardia

stenotic artery or thrombosis (but a confirmation test of coronary vasospasm was not performed). All this confirmed the diagnosis of type 2 acute inferior STEMI with normal epicardial coronary arteries.

Therapy continued in the Coronary Critical Care Unit (CCU) with triple antithrombotic therapy, diltiazem, statin, and continued antidote administration and supportive care. After development of MI, atropine was administered cautiously for the next 2 days, when myosis and signs of exocrine gland hypersecretion appeared. 48 hours after coronary angiography, the patient developed acute renal failure [creatinine $2.15 \mathrm{mg} / \mathrm{dL}$, blood urea nitrogen (BUN)
$87 \mathrm{mg} / \mathrm{dL}$, possibly after contrast substance administration, which was successfully addressed in the Cardiology Department. She was transferred back to our department to complete the medical treatment of MI, OP poisoning, and its complications. For three days she was receiving two units of human plasma a day for exogenous pseudocholinesterase supply, because her level of cholinesterase remained low (1568 U/L) despite obidoxime administration for 72 hours since poisoning. Systolic blood pressure remained below $110 \mathrm{mmHg}$, allowing only a low dose of ramipril as part of the medical treatment of MI. Also, a short episode of nonsustained ventricular 
tachycardia occurred during CCU stay, which was resolved with lidocaine bolus followed by a 24-hour infusion.

During hospitalisation, the patient developed left inferior lobe pneumonia due to infection with Klebsiella pneumoniae, which was treated with ciprofloxacin, mucolytics, and expectorants. Renal function returned to normal, and metabolic and electrolyte derangements were all corrected. The level of HbAlc and fasting glucose were also normal, which ruled out diabetes as a cardiovascular risk factor. The patient was discharged in good condition after 11 days, with ECG showing persistent ischaemic changes in the inferolateral territory (Figure 1D) Cardiac enzymes, liver and renal function, and plasma cholinesterase (5463 U/L) were normal.

\section{DISCUSSION}

Type $2 \mathrm{MI}$ is a heterogeneous syndrome, which can be primary or secondary illness and is caused by either acute non atherothrombotic coronary artery disease or other acute noncoronary trigger/illness (9). However, the European or American STEMI guidelines $(10,11)$ make no mention of acute poisoning (e.g., carbon monoxide, OP, or cyanide poisoning) as possible cause. OP poisoning can be followed by cardiovascular complications (4) within the first few hours. By inhibiting acetylcholinesterase irreversibly, OPs can cause acetylcholine to accumulate and overstimulate cholinergic synapses in the central nervous system. They can also cause heart dysrhythmia, hypertension, or hypotension $(5,6)$. The distinct features of OP poisoning include prolonged PQ and QT intervals (responsible for ventricular arrhythmia and ventricular fibrillation), ST-T changes, AV block, and bradycardia $(12,13)$. Cardiac toxicity starts with a brief period of increased sympathetic tone followed by prolonged parasympathetic hyperactivity, hypoxemia, acidosis, electrolyte derangements, and a direct toxic effect on the myocardium $(12,14)$. In addition, QT prolongation may be followed by torsade de pointes ventricular tachycardia and ventricular fibrillation (12). Parasympathetic hyperactivity plays a major role in the coronary artery spasm, which is an important factor in the pathogenesis of type 2 MI $(1,13)$.

Our patient developed acute type 2 STEMI approximately six hours after accidental ingestion of an unknown quantity of unknown OP solution. Unknown, as we could not get hold of the bottle she later claimed to have mistaken for a drink. She confirmed her chronic occupational OP exposure in a statement about her work conditions and the use of pesticides in her household. Unfortunately, our laboratory was not equipped to assess pesticide blood level or its metabolites in urine as markers of chronic OP exposure. However, we did confirm it by establishing low serum butyrylcholinesterase (BChE) activity in a routine screening test (15). This and the history of exposure, pesticide breath odour, and clinical signs and symptoms including high blood pressure and tachycardia on ED admission pointed to nicotinic symptoms of OP poisoning. We were also aware that tachycardia could have been caused by ethanol intoxication, confirmed by the level of blood alcohol, but later developments proved our OP poisoning diagnosis right.

Pesticides can increase the amount of catecholamines and other vasoactive amines, which can cause coronary thrombosis or spasm and eventually lead to myocardial infarction(16). Ischaemic ECG changes that followed (new ST-segment elevation by $\geq 1 \mathrm{~mm}$ and $\mathrm{T}$ wave inversion), a rise in cTnI, regional wall motion abnormality, and normal epicardial coronary arteries on angiography reinforced our

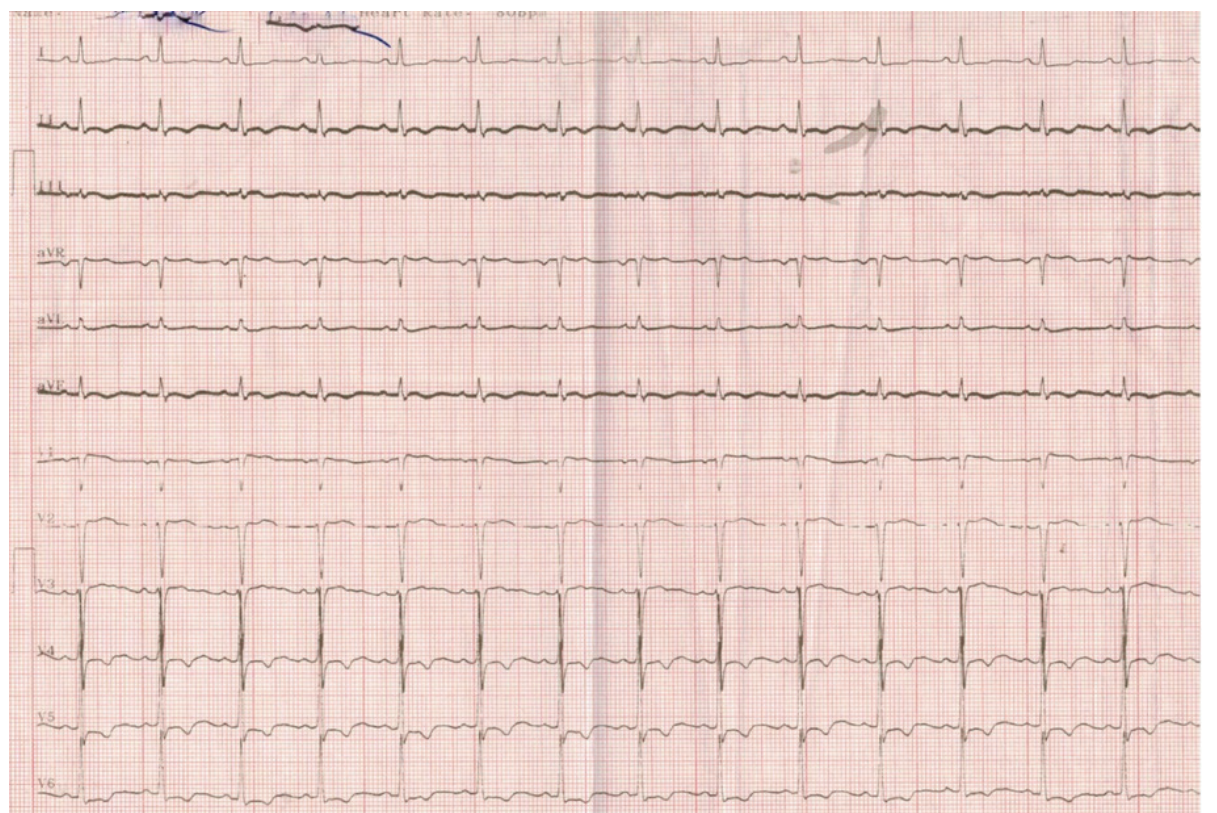

Figure 1D Electrocardiogram monitoring showing acute STEMI in inferior territory. ECG before discharge showing persistence of ischaemic changes in the inferolateral territory 
initial diagnosis of a type 2 MI. We did not have the criteria to diagnose myocardial infarction with non-obstructive coronary arteries (MINOCA), because the Cardiology Department did not test the patient for coronary spasm, and coronary angiography did not reveal microvascular dysfunction, thrombosis, embolism, plaque disruption, or spontaneous coronary artery dissection. Further testing (17, 18) excluded inherited or acquired hypercoagulable state.

The therapy the patient received needs a separate discussion, since there are no specific recommendations in the STEMI guidelines $(10,11)$ for this aetiology of type 2 MI. Given that we blamed coronary vasospasm for the infarction, we chose diltiazem over a beta-blocker for the treatment.

Close monitoring of ECG changes in the ED and later is very important and can inform further treatment, including antidote administration and supportive care (19).

Consistent with acute illness, we interpreted high glucose in our patient as stress-induced hyperglycaemia.

When our patient developed nonsustained ventricular tachycardia five days since OP exposure, her cholinesterase and potassium level were normal. This is why we associated it with STEMI and electric instability and not as direct toxic damage or hypokalaemia. As the changes in serum cholinesterase activities have been implicated in MI, acetylcholinesterase and butyrylcholinesterase can serve as diagnostic markers for the parasympathetic/sympathetic balance and can predict cardiovascular adverse events.

According to Waiskopf et al. (20), about one third of severely poisoned patients have elevated troponin I levels, indicative of MI, and ST depression and/or elevation are more common in patients with elevated TnI. These findings are consistent with our case.

Our search of articles published over the last 15 years and indexed in PubMed, Oxford Journals, Scopus, Google Academic, Science Direct, Springerlink, and Web of Science resulted in only 11 case reports of MI following OP poisoning (see Table 1), which confirms that this is a rare occurrence. MI can occur within hours $(4,19,20)$ or days after acute OP exposure $(16,23,24)$. Two articles $(6$, $25)$ report type $1 \mathrm{MI}$ early after OP exposure. One report (23) refers to a patient poisoned with OP who presented with out-of-hospital cardiac arrest. This patient was successfully resuscitated, the initial ECG showed inferolateral ST segment elevation (possible after defibrillation), although no coronary artery lesions were documented and no troponin elevation recorded. This patient does not meet the criteria for diagnosing MI (1). Another paper (3) refers to MI occurring seven days after parathion ingestion (based on the echocardiography and troponin and CKMB levels), but coronary angiography revealed a $20 \%$ stenosis of the left anterior descending coronary artery consistent with patient's known history of diabetes, and there is no mention of ECG. Because of such a delay between OP poisoning and MI, we think that the two acute events are associated rather than causally related (27). Finally, one paper (28) reported STEMI shortly after OP exposure in a young patient, with patent coronary arteries on angiography, which might suggest type $2 \mathrm{MI}$, but it does not mention occupational exposure to OP.

Our case is particular inasmuch as our patient had no cardiovascular risk factors, had been occupationally

Table 1 Case reports of myocardial infarction following organophosphate poisoning

\begin{tabular}{|c|c|c|c|c|c|}
\hline Author & $\begin{array}{l}\text { Onset after OP } \\
\text { exposure }\end{array}$ & $\begin{array}{c}\text { Type of } \\
\text { poisoning }\end{array}$ & $\begin{array}{l}\text { Type of myocardial } \\
\text { infarction }\end{array}$ & Coronary angiogram & Outcome \\
\hline $\begin{array}{l}\text { Tkaczyk Jędrzej et } \\
\text { al. (25) }\end{array}$ & $\begin{array}{l}\text { In the same day, } \\
\text { after admission }\end{array}$ & Voluntary & Type 1 & $\begin{array}{c}\text { Three-vessel coronary } \\
\text { disease }\end{array}$ & Dead \\
\hline $\begin{array}{l}\text { Karasu-Minareci et } \\
\text { al. (6) }\end{array}$ & After $1-2 \mathrm{~h}$ & Accidental & Type 1 & $\begin{array}{l}90 \% \text { stenosis of the } \\
\text { right coronary artery }\end{array}$ & Recovered \\
\hline Ayyadurai et al. (28) & Upon admission & Voluntary & Type 2 & Patent coronaries & Recovered \\
\hline Kidiyoor et al. (3) & After 7 days & Voluntary & Type 2 & $\begin{array}{c}\text { Left anterior } \\
\text { descending coronary } \\
\text { artery } 20 \% \\
\text { obstruction (autopsy) }\end{array}$ & Dead \\
\hline Kuo et al. (26) & $\begin{array}{c}\text { Second night } \\
\text { after admission }\end{array}$ & $\begin{array}{c}\text { Not } \\
\text { specified }\end{array}$ & Inferolateral STEMI & $\begin{array}{c}\text { No stenotic artery or } \\
\text { thrombosis }\end{array}$ & Dead \\
\hline Pankaj and Krishna (24) & After 5 days & $\begin{array}{c}\text { Not } \\
\text { specified }\end{array}$ & STEMI & Postponed & Recovered \\
\hline Joshi et al. (23) & After 2 days & Voluntary & STEMI & Not performed & Recovered \\
\hline $\begin{array}{l}\text { Aydın and Küçüktepe } \\
\text { (22) }\end{array}$ & At admission & Accidental & STEMI & Not specified & Recovered \\
\hline Kumar et al. (16) & After 3 days & Voluntary & Inferolateral STEMI & Not performed & $\begin{array}{c}\text { Not } \\
\text { specified }\end{array}$ \\
\hline Mdaghri et al. (21) & After 20 hours & $\begin{array}{c}\text { Not } \\
\text { specified }\end{array}$ & $\begin{array}{l}\text { Endocardial } \\
\text { ischaemia }\end{array}$ & Not specified & Dead \\
\hline Lionte et al. (4) & $\begin{array}{l}24 \text { hours after } \\
\text { admission }\end{array}$ & Voluntary & Anteroseptal STEMI & $\begin{array}{c}\text { Not performed } \\
\text { (pathology confirmed } \\
\text { diagnosis) }\end{array}$ & Dead \\
\hline
\end{tabular}


exposed to pesticides for 10 years, and developed type 2 STEMI within six hours of accidental ingestion. To the best of our knowledge, this is the first case of an acute type 2 MI following accidental poisoning with OP in a patient with chronic occupational exposure to OP pesticides. When there is a short interval (hours) after an acute exposure to OP, it is more likely the relationship between the two situations is causal, and the arguments are clearly demonstrated in literature $(29,30)$. A study which analysed pesticide use and MI incidence among farm women (31) revealed an increased risk of MI associated with low-level pesticide exposure in women. This might explain the occurrence of type $2 \mathrm{MI}$ in our patient within six hours of accidental ingestion of an OP pesticide solution.

In most reports reviewed by DeFilippis et al. (32), patients classified as having a type 2 MI were older, more often female, with more comorbidities, and a lower peak in cTnI. This was the case with our patient too.

Patients with type $2 \mathrm{MI}$ have higher short- and long-term mortality than those with type 1 MI (20), and in-hospital mortality rates are 2-3 times higher than those reported for type $1 \mathrm{MI}$ because of non-cardiovascular events (33). A recent study (34) which tested a hypotheses that rise in cardiac troponin T (cTnT) and CK-MB follows a different pattern between type 1 and type $2 \mathrm{MI}$ and that the ratio of cTnT to CK-MB is disproportionately higher in type 2 than type $1 \mathrm{MI}$. It concluded that patients with marked elevations in these biomarkers may be more likely to have type $1 \mathrm{MI}$, whereas those with mildly elevated CK-MB and moderately elevated cTnI may be more likely to have type $2 \mathrm{MI}$, which was also the case with our patient.

Finally, even though lactic acidosis is associated with a higher risk of early death and in-hospital complications $(35,36)$, our patient responded well to the treatment and recovered.

\section{CONCLUSION}

Even though we had no guidelines to fall back on, we successfully treated the patient with low-molecular-weight heparin, antiplatelets, statin, diltiazem, low-dose ramipril, antidote therapy, and supportive care. We hope that the existing STEMI guidelines should include evidence-based specific treatment for this toxicological emergency. Type 2 MI following OP poisoning is a rarely reported complication and emergency physicians should be aware of this early complication to assess all cardiac biomarkers as soon as a patient is admitted to emergency. This might improve the outcome and prevent fatalities.

\section{Acknowledgements}

We wish to thank our patient for consenting to the publication of this case report (written informed consent available with the corresponding author).

\section{Conflicting interests}

None to declare.

\section{REFERENCES}

1. Thygesen K, Alpert JS, Jaffe AS, Chaitman BR, Bax JJ, Morrow DA, White HD; the Executive Group on behalf of the Joint European Society of Cardiology (ESC)/American College of Cardiology (ACC)/American Heart Association (AHA)/World Heart Federation (WHF) Task Force for the Universal Definition of Myocardial Infarction. Fourth universal definition of myocardial infarction (2018). Circulation 2018;138: e618-51. doi: 10.1161/ CIR.0000000000000617

2. Kim S, Lim JH, Kim Y, Oh S, Choi WG. A case of acute carbon monoxide poisoning resulting in an ST elevation myocardial infarction. Korean Circ J 2012;42:133-5. doi: 10.4070/kcj.2012.42.2.133

3. Kidiyoor Y, Nayak VC, Devi V, Bakkannavar SM, Kumar GP, Menezes RG. A rare case of myocardial infarction due to parathion poisoning. J Forensic Leg Med 2009;16:472-4. doi: 10.1016/j.jflm.2009.05.003

4. Lionte C, Sorodoc L, Petris O, Sorodoc V. [Electrocardiographic changes in acute organophosphate poisoning, in Romainan]. Rev Med Chir Soc Med Nat Iasi 2007;111:906-11. PMID: 18389778

5. Kiss Z, Fazekas T. Arrhythmias in organophosphate poisonings. Acta Cardiol 1979;34:303-23. PMID: 317206

6. Karasu-Minareci E, Gunay N, Minareci K, Sadan G, Ozbey G. What may be happen after an organophosphate exposure: Acute myocardial infarction? J Forensic Leg Med 2012;19:94-6. doi: 10.1016/j.jflm.2011.07.011

7. Chharba ML, Sepaha GC, Jain SR, Bhagwat RR, Khandekar JD. ECG and necropsy changes in organophosphorus compound (malathion) poisoning. Indian J Med Sci 1970;24:424-9. PMID: 5523187

8. Georgidalis N, Konstantinos T, Tsitsimpikou C, Vardavas A, Ramin R, Germanakis I, Tsatsakis A, Stagos D, Kouretas D. Pesticides and cardiotoxicity. Where do we stand? Toxicol Appl Pharmacol 2018;353:1-14. doi: 10.1016/j. taap.2018.06.004

9. Sandoval Y, Thygesen K, Jaffe AS. The universal definition of myocardial infarction: present and future. Circulation $2020 ; 141: 1434-6$. do i : 10.1161/ CIRCULATIONAHA.120.045708

10. Ibanez B, James S, Agewall S, Antunes MJ, Bucciarelli-Ducci C, Bueno H, Caforio ALP, Crea F, Goudevenos JA, Halvorsen S, Hindricks G, Kastrati A, Lenzen MJ, Prescott E, Roffi M, Valgimigli M, Varenhorst C, Vranckx P, Widimský P; ESC Scientific Document Group. 2017 ESC Guidelines for the management of acute myocardial infarction in patients presenting with ST-segment elevation: The Task Force for the management of acute myocardial infarction in patients presenting with ST-segment elevation of the European Society of Cardiology (ESC). Eur Heart J 2018;39:119-77. doi: 10.1093/eurheartj/ehx393

11. Antman EM, Anbe DT, Armstrong PW, Bates ER, Green LA, Hand M, Hochman JS, Krumholz HM, Kushner FG, Lamas GA, Mullany CJ, Ornato JP, Pearle DL, Sloan MA, Smith SC Jr; American College of Cardiology; American Heart 
Association; Canadian Cardiovascular Society. ACC/AHA guidelines for the management of patients with ST-elevation myocardial infarction: a report of the American College of Cardiology/American Heart Association Task Force on Practice Guidelines (Writing Committee to revise the 1999 guidelines for the management of patients with acute myocardial infarction). Circulation 2004;110:e82-e293.

12. Karki P, Ansari JA, Bhandary S, Koirala S. Cardiac and electrocardiographical manifestations of acute organophosphate poisoning. Singapore Med J 2004;45:3859. PMID: 15284933

13. Lionte $\mathrm{C}$, Bologa $\mathrm{C}$, Sorodoc L. Toxic and drug-induced changes of the electrocardiogram. In: Millis R, editor. Advances in electrocardiograms - clinical applications. Rijeka: InTech; 2012. p. 286-8.

14. Ludomirsky A, Klein HO, Sarelli P, Becker B, Hoffman S, Taitelman U, Barzilai J, Lang R, David D, DiSegni E, Kaplinsky E. Q-T prolongation and polymorphous ("torsade de pointes") ventricular arrhythmias associated with organophosphorus insecticide poisoning. Am J Cardiol 1982;49:1654-8. doi: 10.1016/0002-9149(82)90242-9

15. Kapka-Skrzypczak L, Cyranka M, Skrzypczak M, Kruszewski M. Biomonitoring and biomarkers of organophosphate pesticides exposure - state of the art. Ann Agric Environ Med 2011;18:294-303. PMID: 22216802

16. Kumar S, Kumar Divan S, Dubey S. Myocardial infarction in organophosphorus poisoning: Association or just chance? J Emerg Trauma Shock 2014;7:131-2. doi: 10.4103/09742700.130885

17. Tamis-Holland JE, Jneid H, Reynolds HR, Agewall S, Brilakis ES, Brown TM, Cushman M, Kumbhani DJ, Arslanian-Engoren C, Bolger AF, Beltrame JF; American Heart Association Interventional Cardiovascular Care Committee of the Council on Clinical Cardiology; Council on Cardiovascular and Stroke Nursing; Council on Epidemiology and Prevention; and Council on Quality of Care and Outcomes Research. Contemporary diagnosis and management of patients with myocardial infarction in the absence of obstructive coronary artery disease: A scientific statement from the American Heart Association. Circulation 2019;139:e891-e908. doi: 10.1161/CIR.0000000000000670

18. Scarlone G, Niccoli G, Crea F. Editor's choice Pathophysiology, diagnosis and management of MINOCA: an update. Eur Heart J Acute Cardiovasc Care 2019;8:54-62. doi: $10.1177 / 2048872618782414$

19. Sundagaragiri S, Tandur S. Electrocardiographic profile of cardiotoxic plants and animals. Int J Med Res Health Sci 2016;11:719-25.

20. Waiskopf N, Shenhar-Tsarfaty S, Soreq H. Serum cholinesterase activities as biomarkers of cardiac malfunctioning. In: Patel V, Preedy V, editors. Biomarkers in cardiovascular disease. Biomarkers in disease: methods, discoveries and applications. Dordrecht: Springer; 2016. p. 197-218.

21. Mdaghri YA, Mossadeq A, Faroudy M, Sbihi A. Complications cardiaques au cours de l'intoxication aux organophosphorés [Cardiac complications associated with organophosphate poisoning, in French]. Ann Cardiol Angeiol (Paris) 2010;59:114-7. doi: 10.1016/j.ancard.2009.07.005
22. Aydın NB, Küçüktepe Z. Organophosphate intoxication emerging young a case of respiratory failure and myocardial infarction. Selcuk Med J 2014;30:41-3.

23. Joshi P, Manoria P, Joseph D, Gandhi Z. Acute myocardial infarction: can it be a complication of acute organophosphorus compound poisoning? J Postgrad Med 2013;59:142-4. doi: 10.4103/0022-3859.113843

24. Pankaj M, Krishna K. Acute organophosphorus poisoning complicated by acute coronary syndrome. J Assoc Physicians India 2014;62:614-6. PMID: 25672037

25. Tkaczyk J, Brożyna K, Ciechański K, Radzka A, Tchórz M. Fatal pesticide intoxication - case report of a 2 patients. J Educ Health Sport 2018;8:169-74. doi: 10.5281/ zenodo. 1246007

26. Kuo HS, Yen CC, Wu CI, Li YH, Chen JY. Organophosphate poisoning presenting as out-of-hospital cardiac arrest: A clinical challenge. J Cardiol Cases 2017;16:18-21. doi: 10.1016/j.jccase.2017.03.006

27. Höfler M. The Bradford Hill considerations on causality: a counterfactual perspective. Emerg Themes Epidemiol 2005;2:11. doi: 10.1186/1742-7622-2-11.

28. Ayyadurai P, Subbiah G, Selvaraj V. Myocardial infarction following organophosphorus compound poisoning. J Assoc Physicians India 2018; 66:88-9. PMID: 31315337

29. Peter JV, Sudarsan TI, Moran JL. Clinical features of organophosphate poisoning: a review of different classification systems and approaches. Indian J Crit Care Med 2014;18:735-45. doi: 10.4103/0972-5229.144017

30. Cha YS, Kim H, Go J, Kim TH, Kim OH, Cha KC, Lee KH, Hwang SO. Features of myocardial injury in severe organophosphate poisoning. Clin Toxicol (Phila) 2014;52:873-9. doi: 10.3109/15563650.2014.944976

31. Dayton SB, Sandler DP, Blair A, Alavanja M, Beane Freeman LE, Hoppin JA. Pesticide use and myocardial infarction incidence among farm women in the agricultural health study. J Occup Environ Med 2010;52:693-7. doi: 10.1097/ JOM.0b013e3181e66d25

32. DeFilippis AP, Chapman AR, Millis NL, De Lemos JA, Arbab-Zadeh A, Newby LK, Morrow DA. Assessment and treatment of patients with type 2 myocardial infarction and acute nonischemic myocardial injury. Circulation $2019 ; 140: 1661-78$. doi: 10.1161/ CIRCULATIONAHA.119.040631

33. PutotA, Derrida SB, Zeller M, Avondo A, Ray P, Manckoundia $\mathrm{P}$, Cottin Y. Short-term prognosis of myocardial injury, type 1 , and type 2 myocardial infarction in the emergency unit. Am J Med 2018;131:1209-19. doi: 10.1016/j. amjmed.2018.04.032

34. Padney AK, Duong T, Swiatkiewicz I, Daniels LB. A comparison of biomarker rise in type 1 and type 2 myocardial infarction. Am J Med 2020;133:1203-8. doi: 10.1016/j. amjmed.2020.02.024

35. Villar J, Short JH, Lighthall G. Lactate predicts both shortand long-term mortality in patients with and without sepsis. Infect Dis (Auckl) 2019;12:1178633719862776. doi: $10.1177 / 1178633719862776$

36. Lazzeri C, Valente S, Chiostri M, Gensini GF. Clinical significance of lactate in acute cardiac patients. World J Cardiol 2015;7:483-9. doi: 10.4330/wjc.v7.i8.483 


\section{Neobična etiologija infarkta miokarda tipa 2: pregled temeljen na prikazu slučaja}

Otrovanje organofosfatnim pesticidima prilično je često i može dovesti do komplikacija sa srcem i krvožiljem, a ponekad i izravno oštetiti srčani mišić. Do sada, međutim, nije zabilježen slučaj infarkta miokarda tipa 2 . U ovom je radu prikazan slučaj otrovanja 61-godišnjakinje koja je primljena u odjel hitne pomoći jedan sat nakon slučajnoga gutanja nepoznate količine otopine koju je upotrebljavala za suzbijanje biljnih uši. Bolesnica je primljena sa znakovima i simptomima ošamućenosti, mioze, prekomjernoga znojenja, hipersalivacije, urinarne inkontinencije, mišićne fascikulacije, drhtavice u udovima, bljedilom te dahom koji je mirisao na alkohol i pesticide. Premda nije bilo smjernica za liječenje u takvom slučaju, primjena heparina niske molekulske mase, antitrombotika, statina, diltiazema, antidota i potpornoga liječenja dovela je do povoljnog ishoda. Svrha je ovoga prikaza ukazati liječnicima da otrovanje organofosfatima može uzrokovati infarkt miokarda tipa 2, koji se javlja kao komplikacija unutar nekoliko sati od otrovanja, tako da obrada u odjelu hitne pomoći svakako treba obuhvatiti i strogi nadzor srčane funkcije.

KLJUČNE RIJEČI: kardiovaskularni događaji; pesticidi; toksikologija 